\title{
PEMIJAHAN INDUK, PROFIL KOLESTEROL, DAN ASAM LEMAK TELUR LOBSTER PASIR (Panulirus homarus) HASIL BUDIDAYA
}

\author{
Yudha Trinoegraha Adiputra*), Muhammad Zairin Jr.|*, Muhammad Agus Suprayudi*), \\ Wasmen Manalu**, dan Widanarni*) \\ *) Program Pascasarjana IImu Akuakultur, Fakultas Perikanan dan IImu Kelautan, Institut Pertanian Bogor \\ Gedung FPIK IPB, Jl. Agatis, Kampus Dramaga, Bogor, Jawa Barat 16680 \\ *) Departemen Anatomi, Fisiologi dan Farmakologi, Fakultas Kedokteran Hewan, Institut Pertanian Bogor \\ Gedung FKH IPB, JI. Agatis, Kampus IPB Dramaga, Bogor, Jawa Barat 16680
}

(Naskah diterima: 11 M ei 2018; Revisi final: 8 Agustus 2018; Disetujui publikasi: 8 Agustus 2018)

\begin{abstract}
ABSTRAK
Pembenihan lobster pasir (Panulirus homarus) belum berkembang di Indonesia karena terbatasnya teknik pemijahan induk dan belum diketahuinya tingkat keberhasilan induk betina membawa telur dan profil telur hasil pemeliharaan. Penelitian bertujuan untuk mempelajari pengaruh ablasi satu tangkai mata, metode pemijahan massal dan individual pada bulan gelap dan terang pada induk berganti kulit dan membawa telur, serta konsentrasi kolesterol dan asam-asam lemak telur pada lama pengeraman berbeda. Induk betina dan jantan dipakai secara terus-menerus saat percobaan pemijahan. Pemijahan pertama menggunakan pemijahan dengan rasio 2:1 pada bulan gelap. Percobaan kedua dan ketiga menggunakan pemijahan massal selama bulan terang dan gelap. Profil telur dibandingkan konsentrasi kolesterol dan asam lemaknya pada 1, 2, dan 3-4 minggu pengeraman. Hasil penelitian menunjukkan ablasi tangkai mata dapat menstimulasi pemijahan individual dan massal yang didahului dengan ganti kulit pada induk betina sebagai indikator pemijahan. Pemijahan massal pada bulan gelap menghasilkan induk betina membawa telur terbanyak dibandingkan pemijahan individual pada bulan gelap dan pemijahan massal pada bulan terang. Konsentrasi kolesterol dan asam-asam lemak telur mengalami perubahan mengikuti lama pengeraman oleh induk yang menunjukkan terjadinya peningkatan kematangan telur $(P<0,05)$.
\end{abstract}

\section{KATA KUNCl: asam lemak; kualitas telur; lobster pasir; pemijahan; siklus bulan}

ABSTRACT: Brood stock spawning, cholesterol and fatty acids eggs profiles of cultured spiny lobster (Panulirus homarus). By: Yudha Trinoegraha Adiputra, Muhammad Zairin Jr., Muhammad Agus Suprayudi, Wasmen Manalu, and W idanarni

\begin{abstract}
Spiny lobster (Panulirus homarus) hatchery has not been developed in Indonesia. Major constraints were limited broodstock spawning techniques, low incidence of eggs-berried broodstock, and unknown eggs profile. This study aimed to evaluate the effects of eyestalk ablation, spawning methods and moon circulation to molted, the number of eggs berried of females, and eggs-berried cholesterol and fatty acids profiles. Individual and mass spawning during full and new moon were used in this studies. Female and male broodstocks were used for consecutive spawning with ratio 2:1. The first study was used individual spawning during new moon. The second and third studies were used mass spawning during full moon and new moon, respectively. Eggs-berried profile compared concentration of cholesterol and fatty acids during 1, 2, and 3-4 weeks. Results showed eyestalk ablation stimulated individual or mass spawned and molted of female as early indicator of spawning. Full moon and mass spawning supported more eggs-berried female broodstock than that of other methods. Cholesterol and fatty acids showed different concentration within 1, 2, and 3-4 weeks of eggs-berried that supported eggs maturity $(P<0.05)$.
\end{abstract}

\section{KEYWORDS: eggs profile; eyestalk ablation; moon circulation; spiny lobster; spawning}

\footnotetext{
\# Korespondensi: Program Pascasarjana IImu Akuakultur,

Fakultas Perikanan dan IImu Kelautan, Insitut Pertanian Bogor.

Kampus Dramaga, Jl. Agatis, Bogor 16680, Jawa Barat,

Indonesia.

Tel. + 622518622909

E-mail: zairinmz@ live.com
} 


\section{PENDAHULUAN}

Pembenihan lobster pasir (Panulirus homarus) belum berkembang di Indonesia karena tidak adanya teknologi terapan yang dapat diaplikasikan seperti teknologi pembenihan pada udang windu (Penaeus monodon) dan udang vaname (Litopenaeus vannamei) (Adiputra et al., 2018). Teknologi pembenihan lobster pasir yang dibutuhkan di antaranya teknik pemijahan induk dan tingkat keberhasilan induk betina membawa telur, serta profil telur hasil pemeliharaan. Teknik pemijahan induk hanya dimiliki oleh panti benih yang melakukan pembenihan secara lengkap dengan melakukan pemeliharaan induk, maturasi gonad, dan pemijahan induk pada waktu tertentu sehingga dapat mengontrol ketersediaan dan kualitas benih (Primavera, 1988; Meade, 2001).

Induk lobster pasir masih mengandalkan dari tangkapan al am sehingga perlu waktu yang lama untuk beradaptasi sampai dapat digunakan sebagai induk yang reproduktif. Manipulasi hormonal dengan ablasi tangkai mata dapat mempercepat maturasi ovari pada lobster pasir tetapi belum dapat dibuktikan juga berpengaruh pada pemijahan (Radhakrishnan \& Vijayakumaran, 1984). Pemijahan berhubungan dengan organ reproduksi induk dan lingkungan yang menjadi pemicu terjadinya pemijahan di antaranya siklus bulan seperti pada ikan-ikan laut (Taylor, 1984).

Crocos \& Coman (1997) menyebutkan bahwa pengetahuan tentang pola pemijahan pada variasi musim dan ukuran induk krustasea dari alam penting untuk memprediksi performa induk dalam panti benih. Kombinasi antara ablasi tangkai mata, metode pemijahan dan siklus bulan, serta profil telur lobster pasir hasil pemeliharaan belum pernah diteliti sebelumnya. Penelitian ini dilakukan dengan tujuan untuk mempelajari pengaruh ablasi satu tangkai mata, metode pemijahan massal dan individual pada bulan gelap dan terang pada jumlah induk berganti kulit dan membawa telur serta konsentrasi kolesterol dan asam-asam lemak telur pada lama pengeraman berbeda.

\section{BAHAN DAN METODE}

\section{Asal dan Pemeliharaan Induk Lobster Pasir}

Induk lobster pasir betina dan jantan hidup dibeli dari pedagang pengumpul di Krui, Kabupaten Pesisir Barat Provinsi Lampung. Pedagang pengumpul memperoleh lobster dari nelayan setempat. Induk lobster pasir yang sehat, organ tubuh lengkap dan bobot badan yang sesuai dari bak penampungan kemudian dikemas dalam kardus setelah dilumuri pasir kuarsa dan es. Induk lobster pasir dibawa dengan transportasi darat selama 6-8 jam menuju lokasi penelitian di Balai Besar Perikanan Budidaya Laut Lampung di Hanura, Kabupaten Pesawaran Provinsi Lampung. Izin lisan dari Balai Karantina Ikan dan Pengendalian Mutu Hasil Perikanan Provinsi Lampung telah diperoleh untuk menggunakan lobster sebagai bahan penelitian.

Induk lobster pasir betina dengan bobot badan ratarata $160 \pm 23,45$ g/ekor dan lobster pasir jantan dengan bobot badan rata-rata $126 \pm 14,32$ g/ekor dipelihara selama tujuh hari sebagai masa adaptasi terhadap lingkungan dan pakan. Induk dipelihara secara terpisah dengan menggunakan bak fiber berukuran $200 \mathrm{~cm} \times 100 \mathrm{~cm} \times 50 \mathrm{~cm}$ dan $250 \mathrm{~cm} \times 100 \mathrm{~cm} \times 50$ $\mathrm{cm}$ masing-masing sebanyak enam buah. Pemeliharaan menggunakan ketinggian air 40-60 cm dengan pertukaran air dan aerasi dilakukan secara terusmenerus. Pakan yang diberikan berupa daging cumicumi atau ikan segar yang dipotong kecil-kecil sebanyak $5 \%$ bobot badan dan diberikan sebanyak dua kali sehari. Dalam setiap bak pemeliharaan juga diletakkan pipa paralon PVC berdiameter 4 dan 6 inci dan panjang $30 \mathrm{~cm}$ sebanyak $10-15$ buah yang digunakan sebagai pelindung. Pembersihan bak pemeliharaan dan pergantian air total dilakukan pada pagi dan sore hari. Selama masa adaptasi, dilakukan seleksi untuk induk lobster pasir yang akan digunakan untuk pemijahan. Induk lobster pasir yang lemah atau sakit karena tidak dapat beradaptasi dengan lingkungan dan pakan, serta organ tubuh tidak lengkap karena autotomi, tidak digunakan dalam percobaan. Induk lobster pasir betina dan jantan yang terpilih untuk pemijahan diberi penanda berupa angka pada kertas karton dilapisi plastik transparan tahan air dan diikat dengan karet pada bagian cephalothoraks atau telson.

\section{Tahapan Percobaan Pemijahan}

Tiga tahapan percobaan pemijahan induk lobster pasir dilakukan dengan induk betina dan jantan yang dipakai secara terus-menerus dengan rasio 2:1. Pemijahan pertama menggunakan pemijahan individual dengan jumlah induk betina 24 ekor dan induk jantan sebanyak 12 ekor pada bulan gelap dan diulang sebanyak enam kali. Pemijahan kedua dan ketiga menggunakan pemijahan massal dengan jumlah induk betina sebanyak 30 ekor dan jantan sebanyak 14 ekor pada bulan terang dan gelap dengan satu bak pemijahan. Selain mempelajari cara pemijahan pada ketiga percobaan juga dipelajari perilaku induk yang mengerami telur. 


\section{Parameter Pengamatan dan Analisis Data}

Parameter pengamatan yang diamati adalah perubahan warna telur dierami hasil pemijahan sesuai dengan lama pengeraman (minggu), jumlah induk berganti kulit dan jumlah induk membawa telur dengan metode pemijahan dan sirkulasi bulan yang berbeda, morfologi induk (panjang dan bobot badan), berat ovary, dan jumlah telur yang dihasilkan setelah pemijahan. Kolesterol dan asam-asam lemak dari telur hasil pemijahan dengan lama pengeraman 1, 2, dan 34 minggu juga diukur konsentrasinya dan dibandingkan profilnya.

Data hasil pengamatan dalam bentuk kualitatif (perbedaan warna telur lobster pasir hasil pemijahan pada lama pengeraman yang berbeda, jumlah induk betina ganti kulit, induk betina membawa telur, morfologi induk, berat ovari, dan jumlah telur induk betina lobster pasir disajikan dalam bentuk gambar dan tabel. Data hasil pengamatan dalam bentuk kuantitatif terdiri atas konsentrasi kolesterol dan asam-asam lemak telur lobster pasir pada lama pengeraman yang berbeda dianalisis dengan analisis sidik ragam satu arah (one way ANOVA) pada selang kepercayaan 95\% dengan menggunakan perangkat lunak SPSS versi 24 . Analisis sidik ragam yang berbeda nyata kemudian dilanjutkan dengan uji lanjut Tukey.

\section{HASIL DAN BAHASAN}

Pemijahan induk lobster pasir berhasil dilakukan dengan menggunakan induk yang berasal dari alam. Pemijahan terjadi ditandai dengan pergantian kulit pada induk betina setelah 3-5 hari induk betina dan jantan dipelihara dalam bak pemijahan. Proses pergantian kulit induk betina dapat terjadi saat petang dan malam kemudian kulit kembali mengeras selama 5-7 hari berikutnya. Proses pemijahan dapat terjadi selama rentang waktu mengerasnya kulit induk betina tersebut. Proses pemijahan berlangsung cepat pada malam atau dini hari dengan lepasnya secara bersamaan spermatofor (spermatophore) induk jantan dan telurtelur induk betina berwarna merah muda. Proses pembuahan berlangsung di luar alat kelamin dengan posisi betina berada di bawah dan jantan di atas atau kedua induk dalam posisi miring. Setelah pembuahan terjadi, induk betina kemudian menekuk tubuhnya ke arah dalam untuk meletakkan telur satu persatu pada bagian bawah somit (somite). Proses peletakan telur ini membutuhkan waktu cukup lama dan terjadi sepanjang malam. Jumlah induk betina berganti kulit yang mendahului pemijahan bervariasi pada metode pemijahan dan sirkulasi bulan yang berbeda. Jumlah induk berganti kulit pada pemijahan individual pada bulan gelap, pemijahan massal pada bulan terang dan pemijahan massal pada bulan gelap berturut-turut $50 \%$ $53 \%$ dan $80 \%$ dari jumlah induk yang dipijahkan (Tabel 1).

Pemijahan induk lobster pasir yang dilakukan secara individual dengan ablasi satu tangkai mata pada bulan gelap menghasilkan 50\%induk betina membawa telur dan induk betina tanpa ablasi tidak menghasilkan induk membawa telur. Pemijahan induk lobster pasir yang dilakukan secara massal dengan ablasi satu tangkai mata pada bulan terang juga menghasilkan 40\%induk membawa telur dan induk betina tanpa ablasi tangkai mata tidak menghasilkan induk membawa telur. Pemijahan induk lobster pasir yang dilakukan secara massal dengan ablasi tangkai mata pada bulan gelap menghasilkan $73 \%$ induk membawa telur dan induk betina tanpa ablasi tangkai mata menghasilkan 7\% induk membawa telur (Tabel 1).

Perilaku pemijahan pada krustasea merupakan perilaku reproduksi yang melibatkan mekanisme regulasi seksual dan fisiologi antara kedua induk (Barki, 2008). Perilaku pemijahan lobster pasir melibatkan induk jantan dan betina yang diawali dengan penjo do han yang berhubungan dengan rasio pasangan induk dan metode pemijahan (Vijayakumaran et al., 2005). Barki (2008) menyebutkan tiga tahap kompetisi dalam kontes penjodohan di mana betina menjadi pusat kompetisi tersebut. Tiga tahap tersebut yang dimulai dari jantan yang mencari atau menarik betina yang cocok dan melindunginya dari jantan lain, jantan menyediakan kebutuhan betina untuk bertelur atau bertahan dari betina lain, dan sesama betina berkompetisi secara maksimal untuk mendapatkan sperma jantan. Rasio induk betina dan jantan sebesar 2:1 telah memenuhi persyaratan kompetisi tersebut di manajantan dapat memilih betina yang sesuai untuk pemijahan baik dalam pemijahan secara individu atau massal. Hasil penelitian Atema et al. (1979) dan Vijayakumaran et al. (2005) juga konsisten dengan temuan ini bahwa induk sal ing berpasangan pada rasio yang berimbang dapat meningkatkan feromon untuk memijah dan jumlah induk membawa telur.

Ablasi tangkai mata mendorong terjadinya pergantian kulit induk betina kemudian menjadi pemicu terjadinya pemijahan sehingga hal ini dapat digunakan sebagai penanda untuk memperoleh kepastian induk betina lobster pasir akan membawa telur. Jumlah induk dengan ablasi tangkai mata, berganti kulit lebih banyak diperoleh pada pemijahan massal dibandingkan pemijahan individual. Hal ini disebabkan karena lebih besarnya kemungkinan induk jantan mencari pasangan yang sesuai pada pemijahan massal dibandingkan pada pemijahan individual. Sachlikidis et al. (2005) menyebutkan bahwa induk lob- 


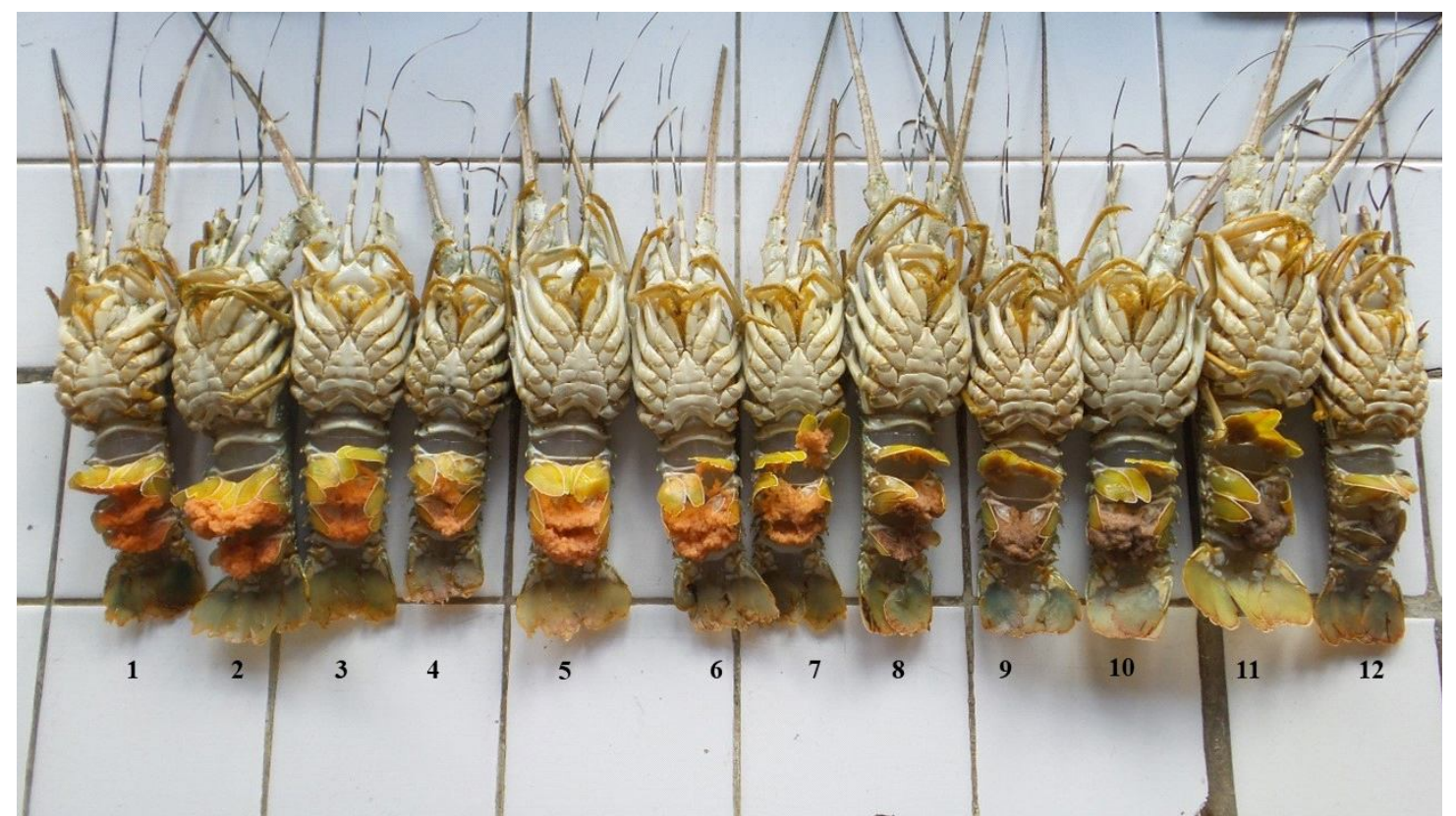

Keterangan: Induk nomor 1-4 telur berumur satu minggu, nomor 5-8 telur berumur dua minggu, dan nomor 9-12 telur berumur 3-4 minggu

Note: $\quad$ Number 1-4 one week age eggs, number 5-8 two weeks age eggs, and number 9-12 three-four weeks age

Gambar 1. Induk betina lobster pasir (Panulirus homarus) membawa telur dengan variasi umur telur.

Figure 1. Female brood stock of spiny lobster (Panulirus homarus) with eggs-berried at various egg stages.

ster mutiara (P. ornatus) yang berganti kulit menjadi indikator pemijahan dapat dilakukan, dengan waktu yang bervariasi.

Pada percobaan ketiga juga ditunjukkan bahwa induk betina lobster pasir tanpa ablasi tangkai mata juga dapat melakukan pemijahan dan memperoleh induk betina membawa telur. Hal ini menunjukkan bahwa potensi pemijahan tidak perlu didorong dengan ablasi tangkai mata tetapi dapat juga dilakukan mencari metode baru untuk mendorong induk betina untuk melakukan ganti kulit. Hal yang dapat dilakukan di antaranya melalui manipulasi lingkungan dengan menaikkan suhu air atau feriodisitas yang diperpanjang (Sachlikidis et al., 2005) atau manipulasi pakan melalui pemberian pakan hidup dengan kandungan kalsium yang tinggi untuk merangsang ganti kulit (Rathinam et al., 2009).

Proses pemijahan yang dilanjutkan dengan peletakan telur pada lobster pasir yang sama prosesnya dengan Homarus americanus (Atema \& Voigt, 1995) dan Jasus edwardsii (McCoy, 1979). Pemijahan massal juga menghasilkan induk betina membawa telur terbanyak dibandingkan pemijahan individual, tetapi telur yang dierami oleh induk betina dalam jangka waktu pendek kemudian dilepaskan yang diduga karena induk stres oleh gangguan oleh induk jantan atau induk lainnya. Tindakan yang dapat dilakukan dengan memindahkan induk betina membawa telur pada tempat terpisah. Pada pemijahan ketiga, telur hasil pemijahan tidak dilepaskan karena perbaikan cara pemeliharaan dengan memisahkan induk betina sehingga dapat dierami dari awal peletakan oleh induk betian sampai matang (Gambar 1). Smith \& Ritar (2005) menguatkan hasil ini bahwa gangguan fisik pada induk betina mengganggu performa reproduksi bahkan sampai larva yang dihasilkan.

Sirkulasi bulan juga memengaruhi jumlah induk betina berganti kulit dan jumlah induk betina membawa telur. Pemijahan pada bulan gelap menunjukkan induk berganti kulit kemudian dilanjutkan dengan memperoleh induk membawa telur yang paling banyak. Meskipun tidak dipengaruhi secara langsung karena lobster pasir dipelihara dalam wadah pemeliharaan tetapi sirkulasi bulan diduga tetap memengaruhi siklus reproduksi melalui sinkronisasi perkembangan ovari yang konsisten dengan sirkulasi bulan (Taylor, 1984), seperti yang terjadi pada Abudefduf saxitilis dan A. troschelii (Foster, 1987) dan kepiting (Skov et al., 2005). Hal ini sesuai dengan hasil yang ditunjukan bahwa induk betina yang sama melakukan pemijahan pada bulan gelap dengan pemijahan individual dan pemijahan massal yang berselang sekitar satu bulan yang kemungkinan merupakan waktu yang dibutuhkan oleh ovari untuk 


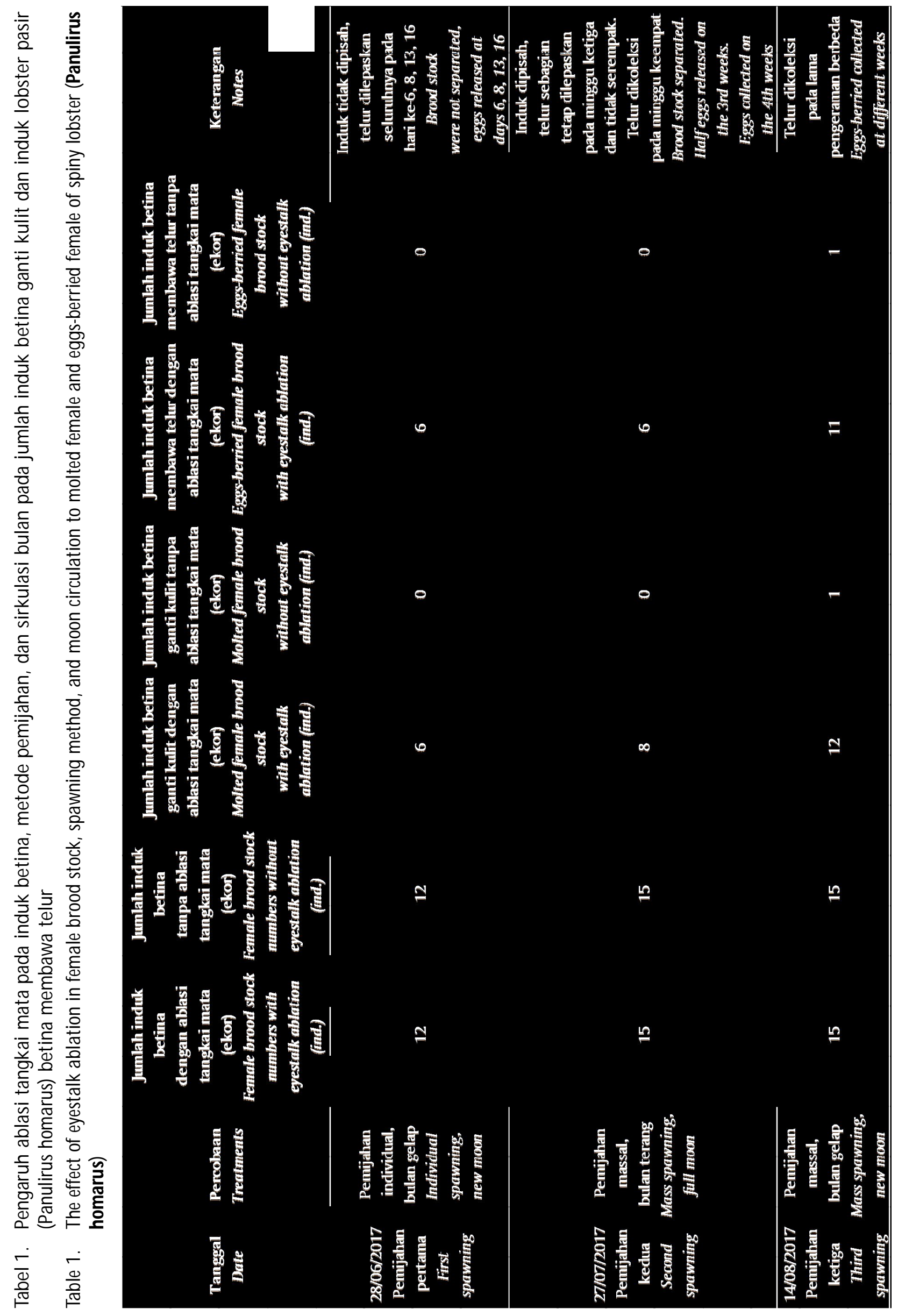


Tabel 2. Bobot badan, panjang total, berat ovari, dan jumlah telur induk betina lobster pasir (Panulirus homarus) yang memijah dengan metode pemijahan berbeda

Table 2. Body weight, body length, ovary weight, and eggs number of female brood-stock spiny lobster (Panulirus homarus) spawned with different methods

\begin{tabular}{|c|c|c|c|c|}
\hline $\begin{array}{c}\text { Bobot badan } \\
\text { Body weight } \\
\text { (g) }\end{array}$ & $\begin{array}{l}\text { Panjang total } \\
\text { Body length } \\
\text { (cm) }\end{array}$ & $\begin{array}{c}\text { Berat ovari } \\
\text { Ovary weight } \\
\text { (g) }\end{array}$ & $\begin{array}{l}\text { Jumlah telur (ekor) } \\
\text { Eggs number (pieces) }\end{array}$ & $\begin{array}{l}\text { Keterangan } \\
\text { Notes }\end{array}$ \\
\hline 184 & 18,8 & \multirow{5}{*}{$\begin{array}{l}\text { Tidak diukur untuk } \\
\text { pemijahan kedua } \\
\text { Not measured for } \\
\text { the second spawning }\end{array}$} & \multirow{5}{*}{$\begin{array}{l}\text { Tidak dihitung karena } \\
\text { dilepaskan induk } \\
\text { Not counted due } \\
\text { to eggs released }\end{array}$} & \multirow{5}{*}{$\begin{array}{l}\text { Ablasi satu tangkai mata; } \\
\text { pemijahan pertama } \\
\text { Eyestalk ablation; } \\
\text { first spawning }\end{array}$} \\
\hline $\begin{array}{l}150^{*} \\
167\end{array}$ & $\begin{array}{l}16,8^{*} \\
17,4\end{array}$ & & & \\
\hline $164^{*}$ & $17,3^{*}$ & & & \\
\hline $216^{*}$ & $20,2^{*}$ & & & \\
\hline $140^{*}$ & $16,4^{*}$ & & & \\
\hline 142 & 16,2 & \multirow{6}{*}{$\begin{array}{l}\text { Tidak diukur untuk } \\
\text { pemijahan ketiga } \\
\text { Not measured for } \\
\text { the third spawning }\end{array}$} & \multirow{6}{*}{$\begin{array}{l}\text { Tidak dihitung } \\
\text { karena dilepaskan } \\
\text { induk dan dikoleksi } \\
\text { Not counted due to eggs } \\
\text { released and collected }\end{array}$} & \multirow{6}{*}{$\begin{array}{c}\text { Ablasi satu tangkai mata; } \\
\text { pemijahan kedua } \\
\text { Eyestalk ablation; } \\
\text { second spawning }\end{array}$} \\
\hline 149 & 16,7 & & & \\
\hline 195 & 19,1 & & & \\
\hline 148 & 16,6 & & & \\
\hline 189 & 18,6 & & & \\
\hline 144 & 16,4 & & & \\
\hline 135 & 16,3 & 1,722 & 3,966 & \multirow{5}{*}{$\begin{array}{l}\text { Ablasi satu tangkai mata; } \\
\text { pemijahan ketiga } \\
\text { Eyestalk ablation; } \\
\text { third spawning }\end{array}$} \\
\hline 160 & 17,7 & 1,200 & 1,636 & \\
\hline 123 & 15,6 & 1,320 & 1,689 & \\
\hline 183 & 18,9 & 1,943 & 12,267 & \\
\hline $151^{*}$ & $17,3^{*}$ & 1,545 & 13,067 & \\
\hline $136^{*}$ & $16,3^{*}$ & 1,495 & 25,418 & \multirow{7}{*}{$\begin{array}{c}\text { Tanpa ablasi } \\
\text { tangkai mata; } \\
\text { pemijahan ketiga } \\
\text { Without eyestalk ablation; } \\
\text { third spawning }\end{array}$} \\
\hline 198 & 19,4 & 1,553 & 10,951 & \\
\hline 146 & 16,5 & 3,884 & 15,008 & \\
\hline $169^{*}$ & $17,6^{*}$ & 1,465 & 20,186 & \\
\hline $217^{*}$ & $20,2^{*}$ & 7,005 & 20,537 & \\
\hline 135 & 16,2 & 1,115 & 7,558 & \\
\hline 188 & 19,3 & 2,242 & 13,854 & \\
\hline
\end{tabular}

Keterangan (Note): ${ }^{*}=$ induk yang sama (samebrood-stocks)

berkembang kembali sampai siap dipijahkan. Hal ini juga memberikan petunjuk bahwa penggunaan induk terus-menerus setiap bulan untuk pemijahan tidak akan menguntungkan induk betina karena tidak akan melakukan pemijahan seperti yang diharapkan. Arcos et al. (2005) juga menyebutkan pemijahan terusmenerus berakibat negatif pada larva yang dihasilkan dan merugikan pada siklus reproduksi yang semakin panjang.

Pemijahan induk lobster pasir dapat dilakukan secara individual dan massal pada bulan gelap dan terang dengan ablasi satu tangkai mata dengan induk yang berbeda. Tetapi dengan induk yang sama, pemijahan dapat terjadi pada bulan gelap dengan induk betina dengan ablasi satu tangkai mata. Induk lobster pasir betina yang sama dapat melakukan pemijahan dengan waktu istirahat untuk proses rematurasi selama satu bulan. Sachlikidis et al. (2005) menambahkan bahwa waktu istirahat tersebut juga merupakan istirahat secara fisiologi di antaranya tidak berganti kulit yang akan dibutuhkan pada musim pemijahan berikutnya. Fakta lain menunjukkan bahwa, induk alam lobster pasir dapat memijah rata-rata sebanyak empat kali setahun (Vijayakumaran et al., 2005), sehingga tidak mengejutkan induk lobster pasir betina dapat melakukan pemijahan dua kali dengan adanya waktu istirahat. Hal ini juga menunjukkan bahwa ablasi tangkai mata dapat berakibat berkepanjangan untuk mempertahankan maturasi go nad. Faktor lain yang mendorong kemungkinan besar karena pakan berupa daging cumi-cumi yang dapat memicu vitelogenesis kedua yang kemungkinan disebabkan molekul steroid yang mendorong rematurasi tersebut (Mendoza \& Revol, 1997). 
Tabel 3. Konsentrasi kolesterol dan asam-asam lemak (\%w/w) telur lobster pasir (Panulirus homarus) pada lama pengeraman (minggu) yang berbeda

Table 3. Cholesterol and fatty acids concentration (\%w/w) of eggs-berried (weeks) of spiny lobster (Panulirus homarus)

\begin{tabular}{|c|c|c|c|}
\hline \multirow{2}{*}{$\begin{array}{l}\text { Parameter } \\
\text { Parameters }\end{array}$} & \multicolumn{3}{|c|}{$\begin{array}{l}\text { Lama pengeraman telur (minggu) } \\
\text { Eggs-berried (weeks) }\end{array}$} \\
\hline & 1 & 2 & $3-4$ \\
\hline Kolesterol (Cholesterol) & $3,690 \pm 0.100^{a}$ & $3,555 \pm 0.065^{a}$ & $6,190 \pm 0.210^{b}$ \\
\hline Asam laurik/Lauric acid (C12:0) & $0.025 \pm 0.005^{\mathrm{a}}$ & $0.040 \pm 0.000^{b}$ & $0.040 \pm 0.000^{b}$ \\
\hline Asam miristat/Myristic acid (C14:0) & $0.890 \pm 0.040^{b}$ & $0.840 \pm 0.020^{b}$ & $0.695 \pm 0.005^{\mathrm{a}}$ \\
\hline Asam miristoleat/Myristoleic acid (C14:1) & $0.040 \pm 0.000^{\mathrm{ab}}$ & $0.045 \pm 0.005^{b}$ & $0.035 \pm 0.005^{\mathrm{a}}$ \\
\hline Asam pentadekanoat/Pentadecanoic acid (C15:0) & $0.365 \pm 0.015^{b}$ & $0.355 \pm 0.015^{b}$ & $0.315 \pm 0.005^{\mathrm{a}}$ \\
\hline Asam palmitat/Palmitic acid (C16:0) & $16,375 \pm 0.095^{a}$ & $16,240 \pm 0.620^{a}$ & $16,430 \pm 0.320^{\mathrm{a}}$ \\
\hline Asam palmitoleat/Palmitoleic acid (C16:1) & $2,870 \pm 0.040^{a b}$ & $2,680 \pm 0.110^{b}$ & $2,345 \pm 0.045^{\mathrm{a}}$ \\
\hline Asam heptadekanoat/Heptadecanoic acid (C17:0) & $0.775 \pm 0.025^{\mathrm{a}}$ & $0.760 \pm 0.030^{\mathrm{a}}$ & $0.765 \pm 0.015^{\mathrm{a}}$ \\
\hline $\begin{array}{l}\text { Asam cis-10-heptadekanoat } \\
\text { Cis-10-heptadecanoic acid (C17:1) }\end{array}$ & $0.250 \pm 0.010^{b}$ & 0.230 & 0.225 \\
\hline Asam stearat/Stearic acid (C18:0) & $8,995 \pm 0.025^{b}$ & $8,420 \pm 0.380^{\mathrm{a}}$ & $8,590 \pm 0.220^{b}$ \\
\hline Asam elaidat/Elaidat acid (C18:1nw9t) & $0.150 \pm 0.010^{b}$ & $0.115 \pm 0.005^{\mathrm{a}}$ & $0.150 \pm 0.010^{b}$ \\
\hline Asam oleat/Oleic acid (C18:1w9c) (MUFA) & $10,310 \pm 0.000^{a}$ & $10,345 \pm 0.445^{a}$ & $10,800 \pm 0.230^{\mathrm{a}}$ \\
\hline Asam linoleat/Linoleic acid (C18:2w6c) (PUFA) & $1,555 \pm 0.045^{\mathrm{a}}$ & $1,645 \pm 0.075^{\mathrm{ab}}$ & $1,735 \pm 0.025^{b}$ \\
\hline Asam linoleat-Y/Y-linoleic acid $(C 18: 3(n-6))$ & $0.035 \pm 0.005^{\mathrm{a}}$ & $0.030 \pm 0.000^{\mathrm{a}}$ & $0.020 \pm 0.000^{\mathrm{a}}$ \\
\hline Asam linolenat/Linoleic acid (C18:3(n-3)) & $0.200 \pm 0.010^{c}$ & $0.180 \pm 0.000^{b}$ & $0.140 \pm 0.000^{\mathrm{a}}$ \\
\hline Asam arachidat/Arachidat acid (C20:0 (PUFA)) & $0.435 \pm 0.015^{\mathrm{a}}$ & $0.430 \pm 0.010^{\mathrm{a}}$ & $0.550 \pm 0.010^{b}$ \\
\hline $\begin{array}{l}\text { Asam cis-11-eikosenoat } \\
\text { Cis-11-eikosenoic acid (C20:1) }\end{array}$ & $1,175 \pm 0.035^{\mathrm{a}}$ & $1,060 \pm 0.040^{\mathrm{a}}$ & $1,080 \pm 0.020^{\mathrm{a}}$ \\
\hline $\begin{array}{l}\text { Asam cis-11.14-eikosedienpat } \\
\text { Cis-11.14-eikosedienpat acid (C20:2) }\end{array}$ & $0.470 \pm 0.020^{\mathrm{a}}$ & $0.440 \pm 0.020^{\mathrm{a}}$ & $0.535 \pm 0.015^{b}$ \\
\hline $\begin{array}{l}\text { Asam cis-8.11.14-eikosetrienoat } \\
\text { Cis-8.11.14-eikosetrienoic acid (C20:3w6) }\end{array}$ & $0.065 \pm 0.005^{b}$ & $0.055 \pm 0.005^{\mathrm{a}}$ & $0.050 \pm 0.000^{\mathrm{a}}$ \\
\hline 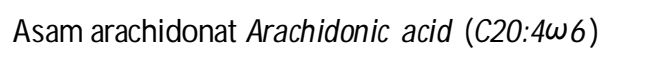 & $3,315 \pm 0.065^{b}$ & $2,800 \pm 0.110^{\mathrm{a}}$ & $3,750 \pm 0.090^{c}$ \\
\hline $\begin{array}{l}\text { Asam cis-5.8.11.14.17-eikosapentaenoat } \\
\text { Cis-5.8.11.14.17-eikosapentaenoic acid (C20:5w3) }\end{array}$ & $5,865 \pm 0.065^{b}$ & $4,475 \pm 0.185^{\mathrm{a}}$ & $5,635 \pm 0.115^{b}$ \\
\hline Asam heneikosanoat/Heneicosanoic acid (C21:0) & $0.055 \pm 0.005^{\mathrm{a}}$ & $0.055 \pm 0.005^{\mathrm{a}}$ & $0.070 \pm 0.000^{b}$ \\
\hline Asam behenat/Behenic acid (C22:0) & $0.255 \pm 0.005^{\mathrm{a}}$ & $0.240 \pm 0.010^{\mathrm{a}}$ & $0.425 \pm 0.015^{b}$ \\
\hline $\begin{array}{l}\text { Asam cis-13.16- dokosadienoat } \\
\text { Cis-13.16- dokosadienoate acid (C22:2) }\end{array}$ & $0.03 \pm 0.000^{a}$ & $0.040 \pm 0.000^{b}$ & $0.045 \pm 0.005^{b}$ \\
\hline $\begin{array}{l}\text { Asam cis-4.7.10.13.16.19-dokosadienoat } \\
\text { Cis-4.7.10.13.16.19-dokosadienoate acid (C22:6w3) }\end{array}$ & $18,350 \pm 0.06^{c}$ & $13,835 \pm 0.565^{b}$ & $12,950 \pm 0.250^{\mathrm{a}}$ \\
\hline Asam trikosanoik/Trichosanoic acid (C23:0) & $0.030 \pm 0.000$ & $0.040 \pm 0.000$ & $0.050 \pm 0.000$ \\
\hline Asam lignoserat/Lignoseric acid (C24:0) & $0.145 \pm 0.005^{\mathrm{a}}$ & $0.155 \pm 0.035^{\mathrm{a}}$ & $0.120 \pm 0.010^{\mathrm{a}}$ \\
\hline 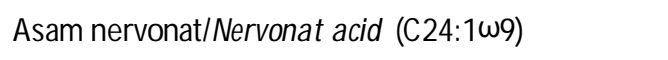 & $0.170 \pm 0.000^{c}$ & $0.145 \pm 0.005^{b}$ & $0.130 \pm 0.000^{\mathrm{a}}$ \\
\hline Asam lemak total (Total fatty acids) & $73,215 \pm 1.405^{b}$ & $65,640 \pm 2.670^{a}$ & $67,675 \pm 2.405^{\mathrm{a}}$ \\
\hline
\end{tabular}

Keterangan: Huruf yang berbeda pada baris yang sama menunjukkan beda nyata pada selang kepercayaan $95 \%$

Note: Different letters on the same row significantly differences at $95 \%$ confidence levels) 
Morfologi induk yang terdiri atas bobot badan dan panjang total, berat ovari, dan jumlah telur induk betina lobster pasir yang memijah dan membawa telur pada ketiga percobaan pemijahan sangat bervariasi (Tabel 2). Terdapat 24 ekor induk betina yang memijah dan membawa telur, masing-masing enam ekor induk pada pemijahan pertama dan kedua dan 12 ekor induk hasil pemijahan ketiga dengan satu ekor induk betina berhasil memijah tanpa ablasi tangkai mata. Terdapat induk lobster betina yang sama sebanyak empat ekor yang melakukan pemijahan dan membawa telur pada percobaan pemijahan pertama, dan pemijahan ketiga. Hasil pemijahan ketiga juga menunjukkan bo bot badan induk berkisar antara 123-217 g/ekor, dengan berat ovari antara 1,12-3,88 g dan jumlah telur yang dihasilkan antara 1.636-25.418 butir/ekor (Tabel 2).

Jumlah telur yang dibawa oleh induk betina selama pengeraman menunjukkan variasi jumlah yang tinggi. Hal ini menunjukkan bahwa tidak ada hubungan antara bobot badan induk, berat ovari, dan jumlah telur yang dihasilkan. Meskipun Smith \& Ritar (2007) melaporkan hal yang berlainan; bahwa terdapat hubungan antara bobot induk betina dengan fekunditas di mana induk betina lebih besar menghasilkan telur dan larva yang lebih banyak. Hasil pada studi ini menunjukkan perlunya pembatasan bobot badan minimal pada induk betina lobster pasir untuk melakukan pemijahan. Hal ini dilakukan untuk mengontrol telur yang berkualitas dan kehilangan telur saat dierami karena bobot induk yang terlalu kecil akan mudah stres karena penanganan (Murugan et al., 2005).

Kandungan kolesterol dan asam-asam lemak telur hasil pemijahan induk pada umur pengeraman 1,2 , dan 3-4 minggu menunjukkan konsentrasi yang bervariasi (Tabel 3). Kolesterol dalam telur menurun konsentrasinya sesuai dengan lama pengeraman dan berbeda nyata antara minggu 1,2 , dan 3-4 $(P<0,05)$. Asam lemak total bervariasi antara minggu 1 dan 2, 3-4 $(P<0,05)$. Asam lemak yang turun konsentrasinya antara lain asam miristat, asam miristoleat, asam pendadekanoat, asam palmitoleat, asam heptadekanoat, asam cis-10-heptadekanoat, asam stearat, asam eladiat, asam lino leate-Ò, asam linolenat, asam cis-8,11,14-eikosetrienoat, asam cis5,8,11,14,17-eikosapentaenoat, asam lignoserat, asam nervonat, dan cis-4,7,10,13,16,19dokosadienoat. Asam lemak yang naik konsentrasinya antara lain asam laurik, asam palmitat, asam oleat, asam linoleat, asam arachidat, asam cis-11-eikosenoat, asam cis-11,14-eikosedienpat, asam arachidonat, asam heneikosanoat, asam behenat, dan asam cis13,16- dokosadienoat (Tabel 3).
Konsentrasi kolesterol dan profil asam lemak telur menunjukkan bahwa terdapat perubahan kandungan kolesterol dan asam-asam lemak yang menunjukkan terjadinya peningkatan kematangan telur $(P<0,05)$. Hal yang sama ditemukan oleh Rosa et al. (2003) dan Arcos et al. (2003) bahwa kualitas telur dapat diamati dengan perubahan paramater biokimia telur dan menurun pada larva yang dihasilkan. Konsentrasi kolesterol yang menurun sesuai umur telur dierami juga teramati pada larva Nephrops norvegius yang menunjukkan penurunan secara drastis kolesterol yang dibawa dari telur sampai tahap perkembangan tubuh akhir. Hal ini kemungkinan penggunaan kolesterol yang digunakan sebagai energi untuk pematangan telur (Rosa et al., 2003). Variasi asam lemak juga ditemukan berfluktuatif dalam percobaan ini. Variasi tersebut menunjukkan terdapat beberapa asam lemak yang berubah kual itasnya menurut umur telur yang dierami yang akan dibutuhkan setelah telur menetas dan perkembangan larva lobster pasir yang diketahui membutuhkan waktu yang panjang.

\section{KESIMPULAN}

Ablasi tangkai mata pada induk betina lobster pasir mempercepat proses pemijahan yang didahului dengan ganti kulit. Pemijahan massal pada bulan gelap dapat menghasilkan induk betina membawa telur lebih banyak dan dapat dipakai terus-menerus dengan waktu rematurasi satu bulan. Konsentrasi kolesterol dan profil asam-asam lemak pada lama pengeraman yang berbeda menunjukkan perubahan kematangan telur hasil pemijahan.

\section{UCAPAN TERIMA KASIH}

Penelitian Disertasi Doktor dari Kemenristekdikti melalui Universitas Lampung dengan kontrak No. 062/ SP2H/LT/DRPM/2018 membiayai penelitian ini yang diterima penulis pertama.

\section{DAFTAR ACUAN}

Adiputra, Y.T., Hudaidah, S., Brite, M., Saputra, A.B., Halim, D.N.A., \& Firmansyah. (2018). Pengembangan perikanan lobster di Provinsi Lampung. Jurnal Inovasi Pembangunan, 6(1), 49-59.

Arcos, F.G., Ibarra, A.M., Palacios, E., VasquezBoucard, C., \& Racotta, I.S. (2003). Feasible predictive criteria for reproductive performance of white shrimp Litopenaeus vannamei: egg quality and female physiological condition. Aquaculture, 228(1-4), 335-349.

Arcos, F.G., Palacios, E., Ibarra, A.M., \& Racotta, I.S. (2005). Larval quality in relation to consecutive 
spawnings in the white shrimp Litopenaeus vannamei Boone. Aquaculture Research, 36(9), 890-897.

Atema, J., Jacobson, S., Karnofsky, E., Oleszko-Szuts, S., \& Stein, L. (1979). Pair formation in the lobster, Homarus americanus: behavioral development pheromones and mating. Marine Behaviour \& Physiology, 6(4), 277-296.

Atema, J. \& Voigt, R. (1995). Behavior and sensory biology. In Factor, J.R. (Ed.). Biology of the lobster Homarus americanus, (p. 313-348). United Kingdom: Academic Press.

Barki, A. (2008). Mating behaviour. In Mente, E. (Ed.). Reproductive Biology of Crustaceans, (p. 223-265). United States: Science Publishers.

Crocos, P.J. \& Coman, G.J. (1997). Seasonal and age variability in the reproductive performance of Penaeus semisulcatus broodstock: optimising broodstock selection. Aquaculture, 155(1-4), 55-67.

Foster, S.A. (1987). Diel and lunar patterns of reproduction in the Caribbean and Pacific sergeant major damselfishes Abudefduf saxatilis and $A$. troschelli. Marine Biology, 95(3), 333-343.

McCoy, J.L. (1979). Mating behavior and egg laying in captive rock lobster, Jasus edwardsii (Crustacea: Decapoda: Palinuridae). New Zealand Journal of Marine \& Freshwater Research, 13(3), 407-413.

Meade, J.W. (2001). Management considerations and economics. In Wedemeyer, G.A. (Ed.). Fish Hatchery Management, (p. 687-705). 2nd Ed. United States: American Fisheries Society.

Mendoza, R., \& Revol, A. (1997). Influence of squid extracts on triggering of secondary vitellogenesis in Penaeus vannamei. Aquaculture Nutrition, 3(1), 55-63.

Murugan, T.S., Remany, M.C., Leema, T.M., Kumar, J.H.A.D., Santhanakumar, J., Vijayakumaran, M., Venkatesan, R. \& Ravindran, M. (2005). Growth, repetitive breeding, and aquaculture potential of the spiny lobster, Panulirus ornatus. New Zealand Journal of Marine \& Freshwater Research, 39(2), 311-315.
Primavera, J.H. (1988). Maturation, reproduction, and broodstock technology. In Biology and culture of Penaeus monodon, (p. 37-57). Phillipines: SEAFDEC.

Radhakrishnan, E.V. \& Vijayakumaran, M. (1984). Effect of eyestalk ablation in the spiny lobster Panulirus homarus (Linnaeus) on gonadal maturity. Indian Journal of Fisheries, 31(2), 209-216.

Rathinam, A.M.M., Kandasami, D., Kizhakudan, J.K., Leslie, V.A., \& Gandhi, A.D. (2009). Effect of dietary protein on the growth of spiny lobster Panulirus homarus (Linnaeus). Journal of Marine Biological Association of India, 51(1), 114-117.

Rosa, R., Morais, S., Calado, R., Narciso, L., \& Nunes, M.L. (2003). Biochemical changes during the embryonic development of Norway lobster, Nephrops norvegicus. Aquaculture, 221(1-4), 507-522.

Sachlikidis, N.G., Jones, C.M., \& Seymour, J.E. (2005). Reproductive cues in Panulirus ornatus. Zealand Journal of Marine \& Freshwater Research, 39(2), 305-310.

Skov, M.W., Hartnoll, R.G., Ruwa, R.K., Shunula, J.P., Vannini, M., \& Cannicci, S. (2005). Marching to a different drummer: crabs synchronize reproduction to a 14-month lunar-tidal cycle. Ecology, 86(5), 1164-1171.

Smith, G.G. \& Ritar, A.J. (2005). Effect of physical disturbance on reproductive performance in the spiny lobster, Jasus edwardsii. Zealand Journal of Marine \& Freshwater Research, 39(2), 317-324.

Smith, G.G. \& Ritar, A.J. (2007). Sexual maturation in captive spiny lobster, Jasus edwardsii, and the relationship of fecundity and larval quality with maternal size. Invertebrate Reproduction \& Development, 50(1), 47-55.

Taylor, M.H. (1984). Lunar synchronization of fish reproduction. Transactions American Fisheries Society, 113(4), 484-493.

Vijayakumaran, M., Murugan, T.S., Remany, M.C., Leema, T.M., Kumar, J.D., Santhanakumar, J., Venkatesan, R., \& Ravindran, M. (2005). Captive breeding of the spiny lobster Panulirus homarus. Zealand Journal of Marine \& Freshwater Research, 39(2), 325-334. 